\title{
The Meaning, Strategies and Application of the Value Creation as a Profit Model
}

\author{
Fanbin Zeng \\ College of Journalism and Communication, Jinan University, Guangzhou 510632, China \\ E-mail: zengfanbin@vip.sina.com
}

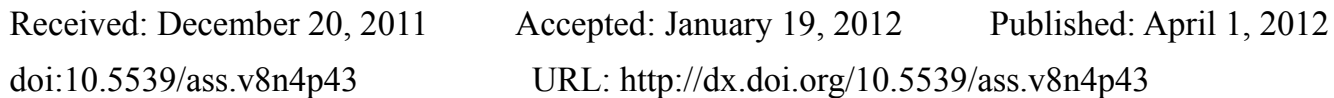

This research thanks for the support by Panmedia Institute ("PMI", http://panmediainstitute.com/) with the items number 20114-008.

\begin{abstract}
To designate the value creation of the news products, it is necessary for the media to take into account its stakeholders. In the future, the core requirement of the media is to satisfy the personalized needs of the audience. Correspondingly, this profit model is called value creation. The value creation refers that the media provide the products to satisfy the personalized needs of the audience, which can improve the audience's paying willingness and increase the media's revenue. There is a priority among the five strategies of the value creation: to provide specialized information products $>$ to provide exclusive information products $>$ to reuse the news through cross-media $>$ to improve the producing and disseminating speed of the news products $>$ to increase the number of the news products. Such a profit model has been applied and the media has gathered some experience.
\end{abstract}

Keywords: Value creation, Profit model, Personalized needs, Paying willingness

\section{Introduction}

Value creation refers to the organization of how to determine and management creates value for shareholders and successful operations and realizes the organization of the value of the main process. Media to determine the value of the news product creation, will in the process of achieve added value considering the stakeholders. The so-called "stakeholders" is to point to a certain interest relationship with the enterprise of the individual or enterprise groups, may be within the enterprise (such as employee), also may be enterprise external (such as supplier or pressure groups). According to Robert skin carter (1989) point of view, and media stakeholders including media owners, audience, advertisers and media staff, social five aspects, the different stakeholders need different value creation, its specific as follows: (1) the media owners of which the goal for the preservation of the organizational assets, high return on investment, asset value added. (2) The audience of which the goal is lower prices for higher quality media products and services. (3) Advertisers of which the goal is a lower price to maximum target audience. (4) Media people of who the goal is to professional status and reasonable compensation. (5) Society of which the goal is to provide a thinking and discussion of the platform, so that it can maintain social order and promoting the development of society.

Media development history shows the different historical period of service stakeholders order is different:

\section{1 party media stage}

The so-called political party media, refers to belong to party group, from political obvious mainly is the propaganda of the party policies and related activities of the media. In the late Qing dynasty before when such as to promote a claim, the gardens of a sino-foreign jamie smell", "the strong journal" and so on, these newspapers have strong political color and political sex. Party media period, important is propaganda media worker's political views, and to participate in social and political life, and for propaganda target audience, work in order to convince the audience accept news media claims, media owners won't or little account of the value of the assets, basic without advertising, therefore, party media for media workers create the highest value, and for society and the audience to create higher value for advertisers and media owners create general value. 


\subsection{The popular media stage}

Mass media, originating from the industrial revolution countries successively appeared after the middle of face the society issued cheap newspapers. Along with the radio, TV after the development, become a kind of most ordinary people to the media. Mass media phase is to take in the content product market and advertising market to sell the profit pattern of dual, and with the development of the media, its increasingly rely on advertising revenue, such as in 1956, the newspaper of the advertising revenue only accounts for $71 \%$ of total revenue, into the 20 the century, is $82 \%$ (Robert G. Picard, 2002), the rapid development of advertising revenue as media owners an important guarantee of earnings. This stage, the audience for media attention that though, but its purpose is to create in the audience circulation or viewing (to) rate, the consideration is most of the audience usually need to, not different between audience individual requirements. For this, the popular media for advertisers and media owners create the highest value, for audience, social and media workers create general value.

\section{3 public media stage}

Public service media refer to the society for the purpose of media, such as the British broadcasting corporation is a funded by the government but the independent operation of public media. Public media from the audience funds directly supply, don't rely on advertising; The program independent of any interest group includes the government; Show consideration a few audience, especially the social hard attend to the needs of the special audience; The contents of the program do not pursue a ratings but pursue program quality, however, this one phase of the program also only consider the overall interests of the public, it doesn't consider different audience individual requirements. Visible, public media for society to create the highest value, for audience, media workers create higher value for advertisers and media owners create general value.

The development history of media from the above three main stages to see, the media are not the personalized needs of the audience in the most important place, so difficult to really important for audience, in order to change this situation, will create a personal media stage, as the future development direction.

\subsection{The future of media--personal media stage}

Personal media stage, refers to the audience is the personalized needs of services as the core of the media, but such an audience, and not the past think of passive, large-scale and even the mob, but on different crowd of change, from different groups of people who demand. Media provide products into the audience go in the life, and maintain contact with the audience, create real value for audience. Personal media stage based on democratic participation in theory, its main ideas have (Guo, Qingguang, 1999): (1) Any personal and social group's people have known, the right of the right of communication through to the media, the use and the close and accept media services, the right. (2) The media should be mainly for the audience and the media organization, advertisers, publicity home exist; (3) the social from all walks of life should have their own media; (4) Small, two-way interactive involvement and the media conform to social ideal. Because consider the audience and the individual interests, audience of media willingness to pay increase, will also drive advertising to quality, and increase the interest of the owners in an advertisers and media. Visible, personal media for audience to create the highest value, but also for the audience, advertisers and media workers, and media owners create higher value.

\section{The connotation of value creation profit model}

So, and personal media stage corresponding is a kind of what kind of profit model? At present, most of the media is based on content product market and advertising market the dual product market media mode profits (chart 1), in the content products in the market, media as a sale to provide information to the audience and the audience is to provide money and (or) time for media, of course, not all media products all need money exchange with the audience, but it is all media products need customer with time the scarce resources to exchange. In the advertising market, on the surface, to sell his media space or time to advertisers, but really the right to sell the audience to media to advertisers. Advertisers to money and media exchange. And here the audience of the right of the approach of the measure for the first market according to measure and essence is the quantity and quality of the audience, and often in the audience as a measure of the media contact time index. Along with the development of the media, relying too much on advertising market for advertising revenue has become the most media mode of operation, is a part of this kind of dual product market profit model of the core. However, relying too much on advertising media attention to the market in the number of lay particular stress on audience and audience of media product payment time, and lack of audience personalized needs attention, lack of the reader to pay money to the attention of the media products, eventually leading to the media products and audience of the products of the pre-paid the lack of money. 
For the average consumer goods for, enterprise concern is for the goods from the consumer of the will of the pay money, this psychology in microeconomics called on willingness to pay. The audience's willingness to pay for the product is refers to the highest willing to pay the price, if its willingness to pay higher than the actual price, then the audience is willing to buy a consumer goods, if its willingness to pay less than the actual price, the audience will give up to buy a consumer goods. In binary product market profit mode, with the advertising market income compensation, the media often with low price and even free media products to attract an audience, so that, even if the audience's willingness to pay is not high, but as long as the price is greater than the actual and the audience will buy this media products. Media also through this strategy expanded audience get more time audience, eventually in the advertising market is profit. However, this strategy often makes the media ignored audience of media products willingness to pay, making it difficult to provide real high quality, meet different audience psychology demand the product, therefore, we should reform the traditional binary product market profit model, a kind of value innovation to create the profit pattern of out. The so-called value creation profit model, refers to the media to provide service audience the personalized needs of products, the media products can help to improve the audience willingness to pay, increase media content in product market in the income, finally off current media excessive rely on advertising revenue this a profit model.

The new value creation profit model to meet the personalized needs of the audience for the core, in order to improve the audience willingness to pay for breakthrough, not only for the audience for value creation, still can give the media in other stakeholders media owners and advertisers, media workers, social value creation. One of the principle as follows: media people through the production service audience the personalized needs of the products, thus get the audience recognition, and further increase the audience willingness to pay and increase the time contact media, the audience increased willingness to pay the content of the media products income, and meet the needs of the economy of the media owners, meet the audience the personalized needs of media products to increase the audience the increase of utility, the effectiveness of each audience increased social utility is actually increase, and the media time increase audience contact prompted the advertisement effect of the increase of advertisers. The profit pattern of value creation can be the following figure 2 to say:

\section{Value creativity profitable mode choice of the strategy}

How to value creation, the media can choose five kind of strategy, however, these strategies and not for all the stakeholders can create the value of the same size, different strategy its specific performance is different, the following one by one to analysis:

\subsection{Increasing the number of news product}

For the audience for, because different audience have different characteristics, with news of the increase in the number of products, and in the audience of diminishing marginal utility law under control, the audience the increase of total effectiveness is first increased and then decreased, the turning point that is marginal utility for zero place, also is the most large utility. Therefore, the audience increase in the number of from news for utility increase can't keep pace with the increase of the number of product news speed and, eventually, because of the information products to increase excessive audience given the overall utility reduced. In addition, although the increase of the excess of the news product may give some small parts of the audience brings about certain utility, but, but to most of the other audience brought to the mass information disposal of the negative utility. As Abraham Maslow's, (Abraham h. Maslow) pointed out that "we can seek knowledge, to reduce the anxiety, and we also can avoid knowledge, and to reduce anxiety (Abraham H. Maslow, 1963). And if news product the quantity is too much, the hard to avoid is prosperous, some news product and is not people required information, and some even is not accurate information, bad information, false information so that more will lead to the value of the assessment of the audience of the decline. To advertisers, it increases the number of news product did not increase the value, but lower value, this is because the audience in order to avoid contact with too much information, do not be willing to pay for more news product time or money, the result makes advertisement hard to get close to the target audience, achieve the purpose to persuade advertising. For media owners for, advertiser's value to the fall in the marginal investment income drop appeared, and its value is also on the decline. For media workers for, increase the quantity of products and news can't improve the quality of the news, but increases media workers the investment of time and energy, too much wasteful consumption make it difficult to creative production news high-quality goods, and also reduced the value of media people. Of course, in the information society, increase the number of news product is often considered an increase information method; therefore, for the society as a whole, increase the quantity of products can give news from the higher value.

\subsection{Improving the production and dissemination of news product speed}

For the audience for, improve the production and dissemination of news product speed is undoubtedly increase 
its value so that the audience can understand the change of the world around them, but also want to see is, the speed of the news product but could damage the news the veracity and reliability of products, and improve the production and dissemination of news product speed and can't necessarily bring high value to the audience. In addition, the speed of the news product to different audience value is different, and news product related audience of the speed is demanding, but other audiences are not necessarily, for example, Iraq suicide bombings news reports of the speed to the life of the people in Iraq and is closely related with its people have important value, but for others but not necessarily. So, to the whole audience for, in the guarantee the accuracy, under the premise of the news product production and dissemination of the speed of its value is first increased and then decreased, so promote news product production and transmission speed can only give the audience the increased value of bring part. For advertisers for, the speed of the news product enhancement, and can't affect its close to the quantity and quality of the audience, so the value of no effect. And for media owners for, the speed of the news product has become a common phenomenon, it can't directly to the way the media obviously increase income, so can think is no influence on the value. For media worker, is improve the production and dissemination of news product speed to facilitate its spread the news for the first honor and profit, however, too much speed, is likely to lead to media workers to focus on publish short news or not complete the news, this reduces the professional level of the workers of the media, and finally make it loses relevant professional award, so its value belongs to the part of the decline. Of course, for the society as a whole, and improve the production and dissemination of news product speed can make the information society the operation speed, but too quick to the accuracy of the information that decline as the value added a discount, so also just bring the increased value of part.

\subsection{Using cross media repeated use news product}

In recent years, the news agency attached great importance to use cross media repeated use news product, I wish that could produce scope economy. This strategy is based on the use of the fusion of the media technology, such as the newspaper publisher is committed to providing through various media (including network, cell phones, etc) provides news and information, because "smart publishers know, their survival depends on whether it can at any time, any place contact to the audience" (Martha L. Stone, 2006). To the audience for, use cross media repeated use news product and can't increase its value, because cross media repeated use the spread of news product, make the audience in different media sees the same product news, results in its value dropped. To advertisers for, use cross media repeated use news product, ads are also attached to launch of, and help to increase the number of the target audience to visit and frequency and the advertisement effect for is convinced the favorable, as repeated can increase the effect of persuaded, but too much repetition will backfire, therefore can only is to promote the increased value of the part. The owner of the media for cross media repeated use news product can increase income, share the cost, and along with the news product the repeated use of the increase of value and the degree in increasing. For media workers for, use cross media repeated use have good news product, because it can spread their reports, improve their profile, but of a repetition of also can make its reach a bottleneck. For society, and use cross media repeated use products also have some good news, because it can be more widely to spread the information, but the repeated use make the final value of the rise to a certain degree of stopped, therefore, the use of cross media repeated use of news media workers and social products for all to be part of the value added.

\subsection{Providing exclusive news product}

Exclusive news, and that is "people I have no" information, or with a unique the content of the news. For the audience, it provides exclusive news media products, can help in gaining advantage in the life, or make the economic benefits, so as to increase its value. To advertisers, it provides exclusive news media products can increase for the audience close, increase its some value, but because the number of exclusive news product after all is less, so its advertisers to add value is trivial, can be called value is not affected. For media owners, it provides exclusive news product, because the economic value of scarcity lead to higher, so as to increase the income, and then to the media owners, but in reality, this advantage is limited, as the exclusive products provide income often is limited, and thus belong to part of the value added. For media workers, provide exclusive news product can increase its value, because it can create an internal and professional incentive, such as for journalism awards, etc. To society, from short-term said, exclusive news can and other different media news operation distinguish with exclusive news media get sustainable development. But, in the long term, because of its exclusive and weaken the widely to provide information for the society of social benefit, so as to reduce the value of the whole society, so the exclusive products to the community, it is to belong to part of the value added.

\subsection{Providing professional news product}

Professional news products are for specific industries, special field of the special conditions, special 
phenomenon, special requirements, and professional cover news. Due to the use of high value, professional news than general news can produce more of the exchange value. For the audience, it professional news especially personalized professional news, the work and life has to have the help very much, so it can increase its value. To advertisers, its professional news with clear population statistics of the audience, although the number of single professional news and not many more, but the precise to advertisers to target audience, to increase its value. The owner of the media for professional news can provide high added value for audience of news, so that the audience increased willingness to pay, and then increase the income of the media, and to increase the value of professional journalism. For media worker, is professional news also increased its value, because professional news by expert knowledge for production, and is interested audience produce professional content, which get the strong professional rewards, and increase its value. For the society as a whole, the increase of professional journalism can make the information society the quality improvement, but if each individual choice of professional news too scattered, can reduce social should share the cultural values and knowledge, can also lead to its value to society's down, so can only called value part increased.

These five strategies for all the stakeholders to provide different results can the following table 1 to reflect:

We can see from table 1 that increasing the quantity and improve the product news news product production and in the rate of spread and do not increase the overall value of all the stakeholders, while using cross media repeated use news products to the part of the stakeholder value has increased, provide exclusive news product and special news product can greatly enhance the value of stakeholders. If these five strategies for sort of words, the priority is as follows:

Provide the special news product $>$ provide exclusive news product $>$ use cross media repeated use news $>$ improve news product and in the rate of spread $>$ increase the number of news product.

Therefore, the media in value creation profit model strategy should be first selection preference in the strategy before choosing one.

\section{The application of value creation profit model}

The profit pattern of value creation in the media application practice of need to pay attention to the following questions: first, the profit pattern of value creation is through the production to meet the personalized needs of the audience media products as the means, in order to improve the audience willingness to pay for the key, but not unilaterally to take charge of the media form can be achieved. In addition, the media product charge will be to lose other would not pay for the cost of the audience's contact, and advertising revenue the influence. For example, the New York times from online in May 2005 started "times of hits" (Time Select) column charge, this column is mainly columnist articles, in the second quarter of 2007, online edition "times Select" subscriber per month in as many as 220000 people, but on August 8, 2007 times the company announced the cancellation charge system, here's why on the surface, the number of online readers are not beyond its commercial expectations, advertising is no this follow-up, but actually it's "times of hits" and not really can satisfy the audience the personalized needs of media products.

Secondly, in the traditional media environment, and meet the audience the personalized needs of media products relying mainly on market segments, however, due to the scale of the economic constraints, such a product production is difficult to realize, in media mergence environment, with the aid of the Internet and digital, meet the audience the personalized needs of media production possible and reality. For example, December 8, 2009 associated Press news, the New York Times, the Washington post and Google Company hand in hand to produce new products: Living Stories (fresh story). Specific means is provided by Google technology platform, will the New York Times and the Washington post news consolidation and according to news events divided into different projects, so in every news project, users can see continuously updated news. "Fresh story" change the news to present the way, it will all content polymerization to a dynamic web pages, and on the basis of different news to organize information (as a by the New York times and the Washington post news automatically generated project page). The system is also will be the last time the content of the attention according to the audience to his interest news to the latest news. "Fresh story" provides a new form of interaction with the news, reports of high quality and the audience wants to see the news to be automatic presented to him (Gao, Jinping, 2010). The development of technology that meet the audience the personalized needs of media production of become more easily.

Finally, in the current media production to meet the personalized needs of the audience to realize media products, increase the products and provide the special news exclusive news product supply will increase the willingness to pay the audience. For example, in 2007, the Wall Street journal website has become the world's largest paid subscription news sites, with 980000 online subscribers. This is mainly thanks to the Wall Street journal website 
financial news it easier for the reader to create "value", the service in their financial management, investment decision-making reference, this is the other media cannot provide professional news product. In short, the profit pattern of value creation of the reality that the value of the audience application value for the purpose, thus promote other stakeholder value added (this article published in the international press, 2011), please indicate the reprinted).

\section{References}

Abraham H. Maslow. (1963). The Need to Know and the Fear of Knowing. The Journal of General Psychology, Vol. 68, p.122. http://dx.doi.org/10.1080/00221309.1963.9920516

Gao, Jinping. (2010). Analysis on website Operation Strategy of 'Century Newspaper' (in Chinese). Chinese Journalist, 2.

Guo, Qingguang. (1999). Journalism \& Communication (in Chinese). Beijing, China people University Press, pp.139-140.

Martha L. Stone. (2006). A Guide to Practical Convergence: What Every Media Company Must Know About their Future. Dallas: International Newspaper Marketing Association.

Robert G. Picard. (1989). Media Economics: Concepts and Issues. Thousand Oaks, Calif, Sage Publications, p.7.

Robert G. Picard. (2002). Newspaper Ad Revenue Shows Consistent Growth. Newspaper Research Journal, Vol. 23, pp.21-33.

Table 1.

\begin{tabular}{|l|l|l|l|l|l|}
\hline & audience & advertiser & owner & Media owner & society \\
\hline $\begin{array}{l}\text { Increase the number of } \\
\text { news product }\end{array}$ & $\downarrow$ & $\downarrow$ & $\downarrow$ & $\downarrow$ & $\uparrow$ \\
\hline $\begin{array}{l}\text { Improve the production } \\
\text { and dissemination of } \\
\text { news product speed }\end{array}$ & $\nearrow$ & - & - & $\searrow$ & $\nearrow$ \\
\hline $\begin{array}{l}\text { Use cross media repeated } \\
\text { use news product }\end{array}$ & $\downarrow$ & $\nearrow$ & $\uparrow$ & $\nearrow$ & $\nearrow$ \\
\hline $\begin{array}{l}\text { Provide exclusive news } \\
\text { product }\end{array}$ & $\uparrow$ & - & $\nearrow$ & $\uparrow$ & $\nearrow$ \\
\hline $\begin{array}{l}\text { Provide the special news } \\
\text { product }\end{array}$ & $\uparrow$ & $\uparrow$ & $\uparrow$ & $\uparrow$ & $\nearrow$ \\
\hline
\end{tabular}

$\uparrow=$ increase; $\downarrow=$ decrease; $r=$ increase partly;

$\searrow=$ decrease partly; - no effect

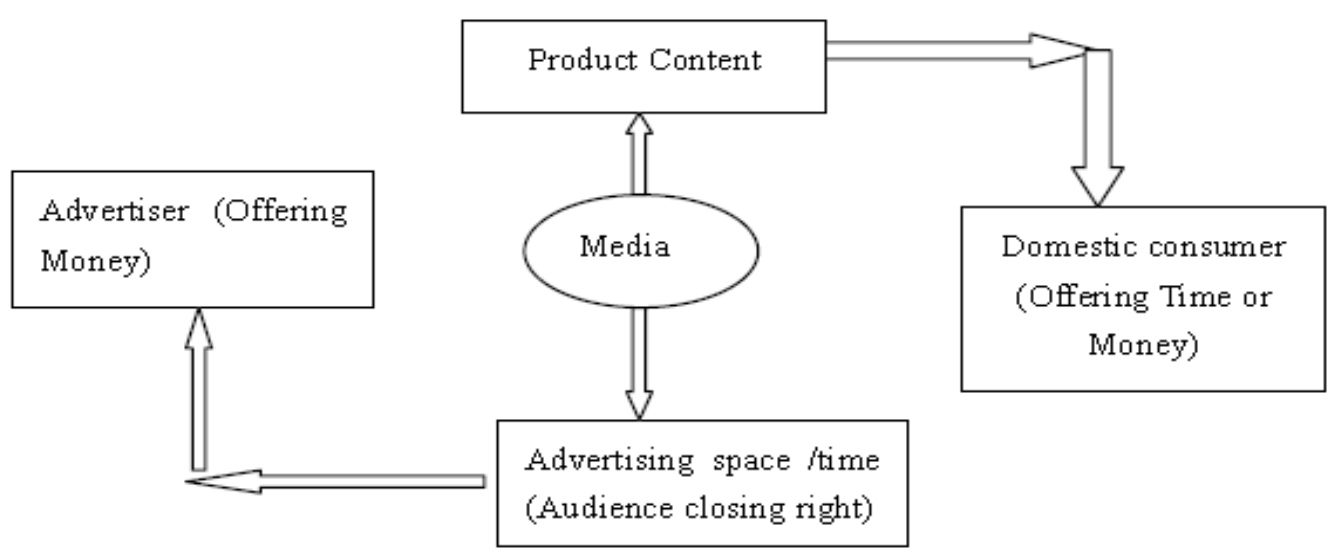

Figure 1. Two products market profit model 


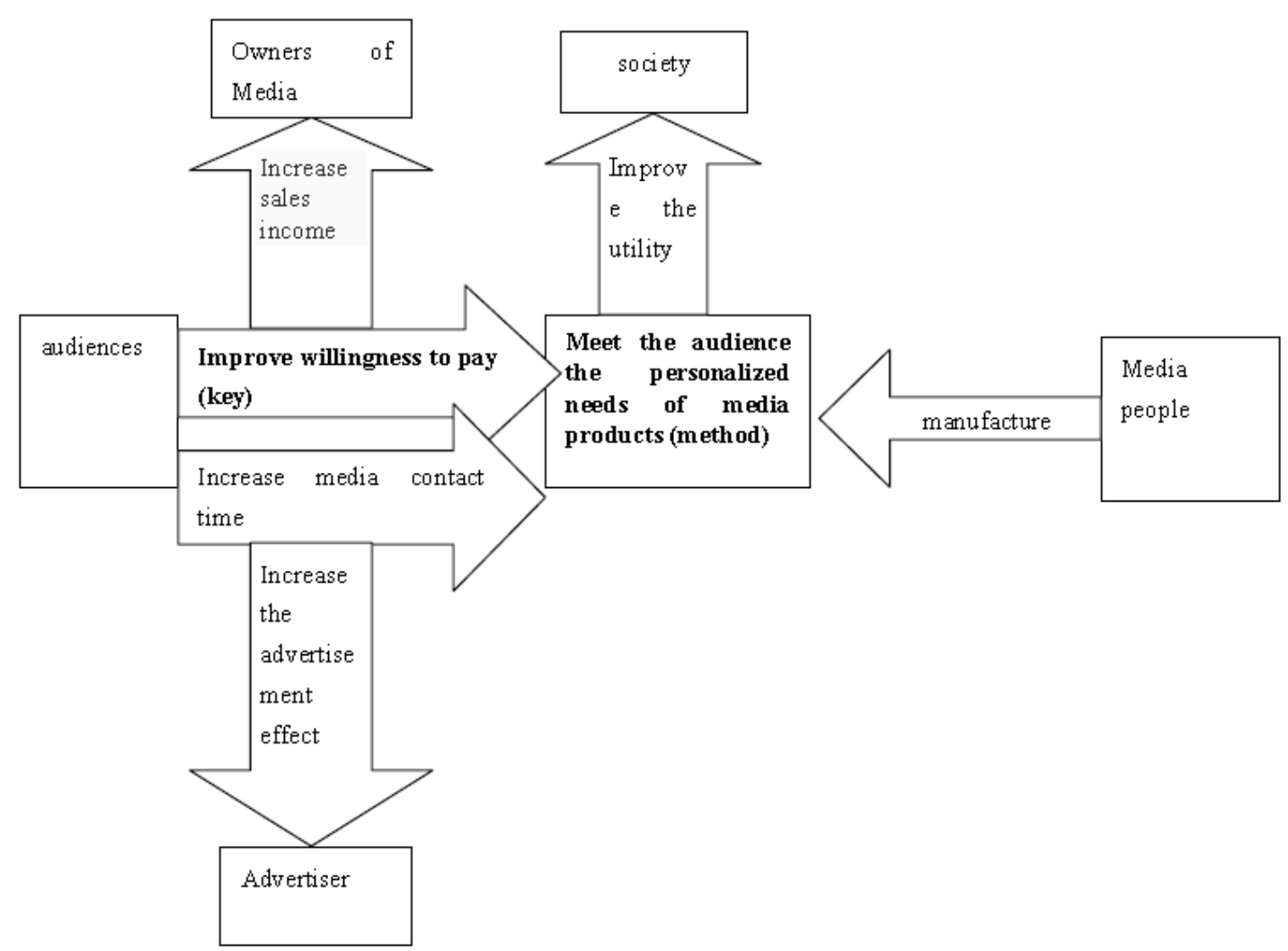

Figure 2. The profit pattern of value creation 